\title{
PERAN SENTRA INDUSTRI GERABAH MELIKAN DALAM PENGEMBANGAN KAWASAN PARIWISATA
}

\author{
Gogor Aldi Sundoro', Nur Miladan', Rizon Pamardhi-Utomo'1 \\ ${ }^{1}$ Program Studi Perencanaan Wilayah dan Kota, Fakultas Teknik, Universitas Sebelas Maret
}

\begin{abstract}
Abstrak
Pariwisata menjadi strategi yang telah banyak diterapkan untuk meningkatkan nilai tambah sentra industri rumah tangga. Pemerintah Kabupaten Klaten juga menggunakan strategi tersebut dalam mengembangkan sektor industri rumah tangganya. Sentra Industri Gerabah Melikan merupakan salah satu sektor industri di Kabupaten Klaten yang diterapkan menjadi kawasan pariwisata. Kegiatan wisata di Sentra Industri Gerabah Melikan tidak lepas dari permasalahan, seperti permasalahan terkait fasilitas sentra yang kurang mendukung kegiatan wisata. Berdasarkan masalah tersebut, penelitian ini bertujuan untuk mengetahui komponen kesesuaian fasilitas kawasan Sentra Industri Melikan berdasarkan indikator kawasan pariwisata. Metode pendekatan yang digunakan dalam penelitian ini, yaitu pendekatan kuantitatif, sedangkan analisis yang digunakan merupakan analisis skoring. Pengumpulan data dilakukan dengan cara observasi, kuesioner, dan wawancara. Pembahasan komponen fasilitas sentra industri pada penelitian ini meliputi, area pembuatan gerabah wisata, area terdampak tungku pembakaran, ketersediaan jalan kawasan, jangkauan parkir wisata, ketersediaan tempat sampah kawasan, ketersediaan listrik kawasan, dan kualitas air bersih kawasan. Hasil dari penelitian ini menunjukkan bahwa fasilitas Sentra Industri Gerabah Melikan memiliki kesesuaian sedang dengan nilai 2,2 poin dari rentang 1-3 poin. Berdasarkan hasil tersebut dapat disimpulkan bahwa, fasilitas secara keseluruhan yang menjadi objek penelitian ini masih kurang mampu dalam mendukung Sentra Industri Gerabah Melikan sebagai kawasan pariwisata.
\end{abstract}

Kata kunci: fasilitas; industri kreatif; industri rumah tangga; kawasan pariwisata; sentra industri

\begin{abstract}
Tourism is a strategy that has been widely implemented to increase the value ofhome industries. The Klaten Regency is also implemented the similar strategy. The Melikan Pottery Industry Center is one of the industrial sectors in Klaten Regency, which becomes a tourism zone. Tourism activities at the Melikan Pottery Industry Center has problems related to its facilities that does not support the tourism activities. Based on these problems, this study aims to see to what extent the the Melikan Industrial Center support tourism areas. The method used in this research is a quantitative one, with scoring as technique analysis. Data collection was carried out by means of observation, questionnaires, and interviews. The components of the industry discussed in the study arearea of pottery making, area affected by burning process of the pottery, road networks, tourist parking locations, regional trash bins, area provided by electricity, and the clean water quality in the region. The results of this study indicate that the Melikan Pottery Industry Center facility shows a moderate suitability with a value of 2.2 points from 1-3 points. Based on these results, it can be concluded that the overall facilities in Melikan remain not able yet to support the Melikan Pottery Industry Center as a tourism area.
\end{abstract}

Keywords: creative industry; facilities; home industry; industrial center; tourism area

\section{PENDAHULUAN}

Undang-Undang Nomor 6 Tahun 2014 tentang Desa, merupakan peraturan yang memberi beberapa kewenangan pada setiap desa untuk mengembangkan potensi desa masing-masing (Republik Indonesia, 2014c). Pelaksanaan pengembangan desa dilakukan secara partisipatif oleh masyarakat sebagai upaya pengoptimalan potensi lokal desa tersebut. Salah satu potensi kegiatan yang terdapat di suatu desa adalah kegiatan industri rumah tangga. Industri rumah tangga di berbagai tempat banyak yang memiliki kekhususan yang tidak dimiliki oleh industri lain. Kekhususan suatu industri tersebut tentunya akan sangat mendukung jika diberdayakan dan dikembangkan dalam sektor pariwisata (Antariksa, 2010). 
Kabupaten Klaten merupakan salah satu kabupaten yang juga telah berkembang banyak sentra industri skala rumah tangga. Sentra Industri Gerabah Melikan merupakan salah satu sentra industri kreatif skala rumah tangga yang setidaknya memiliki 176 unit industri gerabah. Sentra Industri Gerabah Melikan terletak di antara Kecamatan Wedi dan Kecamatan Bayat, yaitu sebagian terletak di Desa Melikan Kecamatan Wedi dan sebagian yang lain terletak di Desa Paseban Kecamatan Bayat. Kegiatan industri pada Sentra Industri Gerabah Melikan telah diarahkan menuju ke kegiatan pariwisata oleh Pemerintah Kabupaten Klaten. Pembuatan gerabah di Sentra Industri Gerabah Melikan memiliki kekhususan tersendiri jika dibandingkan dengan kawasan lain, yaitu menggunakan putaran miring dalam proses pembentukan gerabah. Sentra Industri Melikan dalam pembuatannya menggunakan teknik putaran miring yang sulit ditemukan di tempat manapun (Antaqona, 2012). Pembuatan gerabah dengan putaran miring memiliki keunggulan, yaitu waktu pembuatan gerabah yang lebih singkat dibandingngkan dengan menggunakan putaran biasa. Selain itu, Sentra Industri Gerabah Melikan menawarkan beberapa atraksi lain, yaitu wisatawan dapat menikmati pergerabahan dengan berjalan kaki, ataupun wisatawan dapat praktik membuat gerabah.

Kegiatan wisata yang berlangsung pada Sentra Industri Melikan tidak lepas dari beberapa permasalahan, yang utama mengenai ketersediaan fasilitas penunjang dalam melakukan kegiatan wisata. Jaringan jalan yang sempit membuat kegiatan wisata menjadi tidak maksimal. Selain itu, masalah lain yang juga dapat menjadi kendala wisata, yaitu masalah parkir. Sementara itu, kegiatan pariwisata tidak hanya ditunjang oleh keberadaan atraksi karena akan tetap sulit berkembang jika tidak didukung oleh fasilitas publik yang berkaitan dengan kegiatan wisata (Nurmansyah, 2014). Fasilitas-fasilitas yang mendukung kegiatan wisata akan berpengaruh pada kenyamanan wisatawan yang melakukan kunjungan. Kegiatan wisata berbasis gerabah di Sentra Industri Melikan juga harus memperhatikan keberadaan fasilitas pendukungnya. Berdasarkan kondisi-kondisi dari Sentra Industri Melikan tersebut, penelitian ini bertujuan untuk mengetahui bagaimana kesesuaian fasilitas Sentra Industri Melikan untuk mendukung pengembangan kawasan pariwisata.

\section{KAJIAN PUSTAKA}

Sentra industri, menurut Setiawan dalam Purnomo (2016), merupakan kesatuan fungsi fisik berupa lahan, fasilitas, kelembagaan dan sumber daya manusia. Istilah "sentra industri" tidak sama dengan "klaster industri". Adisasmita (2010) mengemukakan dalam bukunya bahwa sentra industri adalah area tertentu yang terdapat dan berkembang berbagai industri yang sejenis. Sedangkan, klaster industri adalah area yang terdapat industri-industri yang saling terkait berdasarkan rantai produksi (Lestari, 2010). Sentra industri merupakan suatu area yang terdapat industri sejenis dengan tidak memperhatikan rantai produksi yang terjadi antar industri sejenis tersebut. Oleh karena itu, sentra industri gerabah dapat diartikan sebagai suatu area yang terdapat berbagai industri gerabah serta memiliki kesamaan fasilitas dan kelembagaan.

Menurut Undang-Undang Nomor 3 Tahun 2014 tentang Perindustrian, menyebutkan bahwa industri merupakan kegiatan mengolah suatu barang menjadi barang dengan nilai lebih tinggi dalam penggunaannya (Republik Indonesia, 2014b). Industri gerabah adalah kegiatan pengolahan dari bahan mentah berupa tanah liat menjadi produk akhir berupa gerabah. Industri gerabah tergolong dalam jenis industri kreatif karena proses pembuatan industri gerabah dilakukan dengan proses yang kreatif, artinya tidak semua pekerja memiliki kesamaan hasil produksi.

Proses pembuatan gerabah secara umum yang telah dipaparkan oleh Hanafi (2010), bahwa pembuatan gerabah dibagi menjadi 6 (enam) tahap, yaitu pengambilan bahan baku, penggilingan bahan baku, proses pembuatan, penjemuran, pembakaran, dan penyempurnaan. Berdasarkan enam tahap tersebut, tahap yang harus diperhatikan, yaitu tahap pembakaran karena pada tahap ini menimbulkan asap sisa pembakaran yang berdampak pada lingkungan sekitar. Oleh karena itu, jika sedikit menyentuh mengenai kepariwisataan sentra gerabah, maka sisa pembakaran gerabah yang berupa asap dapat menjadi gangguan bagi wisatawan dalam melakukan kegiatan wisata (Fikra \& Khaidir, 2019)

Menurut Yoeti (1996), pariwisata adalah perjalanan yang bertujuan untuk bersenang-senang. Proses bersenang-senang ini, menurut Undang-Undang Nomor 10 Tahun 2009 tentang Kepariwisataan, memerlukan dukungan berbagai fasilitas yang biasanya disediakan masyarakat, pengusaha, maupun pemerintah (Republik Indonesia, 2009). Jadi, dapat ditambahkan bahwa proses berpariwisata membutuhkan beberapa hal inti yang menjadi garis bawah, yaitu objek yang dapat menimbulkan kesenangan dan didukung fasilitas-fasilitas penunjang wisata. Sementara itu, jika membahas tentang kawasan pariwisata, maka menurut Inskeep dalam Rusnanda (2016), kawasan pariwisata adalah suatu area yang dikembangkan sebagai kegiatan pariwisata dengan dilengkapi fasilitas dan pelayanan lengkap. Secara lebih spesifik, menurut Satryanto \& Pamungkas (2015) 
ada beberapa hal yang menjadi penting terkait fasilitas yang terdapat di kawasan pariwisata, yaitu jalan, listrik, air bersih, dan persampahan. Pada suatu area yang menawarkan rute wisata, maka terdapat beberapa hal yang harus disediakan di sepanjang rute tersebut, di antaranya tempat sampah. Selain itu, lokasi tempat parkir merupakan faktor yang sangat penting karena secara tidak langsung dapat mempengaruhi wisatawan dalam melakukan kunjungan (Sulistiani \& Munawar, 2018).

Pariwisata dapat digolongkan menjadi beberapa jenis yang setiap jenisnya memiliki pengertian dan ciri khususnya masingmasing. Jenis pariwisata pada penelitian ini lebih mengarah ke wisata kreatif. Wisata kreatif ini berdiri di antara wisata industri kreatif kerajinan dan wisata budaya. Menurut Cidhy (2016), wisata kreatif adalah salah satu jenis wisata yang wisatawannya tidak hanya dapat melihat dan merasakan kebudayaan suatu tempat, tetapi dapat memperoleh pengalaman yang otentik. Pengalaman otentik tersebut didapatkan oleh wisatawan berupa kegiatan pembelajaran berbasis kerajinan tangan dan keunikan budaya lokal. Pada pariwisata berbasis industri gerabah, kegiatan pembelajaran tersebut merupakan pembelajaran pembuatan gerabah. Kegiatan tersebut haruslah memerlukan fasilitas berupa tempat pembuatan gerabah untuk wisatawan yang berkunjung.

Kesesuaian fasilitas pelayanan pada Sentra Industri Melikan ditinjau dari beberapa hal, yaitu kesesuaian lokasi atau tempat pembuatan gerabah yang digunakan khusus untuk wisatawan, dan beberapa hal terkait ketersediaan jalan, ketersediaan listrik, kualitas air bersih, dan jangkauan tempat sampah. Selain itu, fasilitas pelayanan juga membahas tentang gangguangangguan wisata yang ditimbulkan dari keberadaan tungku pembakaran industri, yaitu mengenai gangguan akibat asap sisa pembakaran. Terdapat dua sub komponen yang memiliki kesesuaian tinggi, yaitu sub komponen kesesuaian tempat pembuatan gerabah khusus wisatawan dan sub komponen area terdampak tungku pembakaran.

\section{METODE PENELITIAN}

Metode pendekatan yang digunakan dalam melakukan penelitian, yaitu kuantitatif. Metode kuantitatif adalah pendekatan yang dilakukan menggunakan suatu pengukuran atupun perhitungan dengan menggunakan angka-angka yang obyektif. Sementara, penelitian ini data diperoleh dengan cara observasi lapangan, wawancara, dan kuesioner. Observasi lapangan dilakukan pada seluruh kawasan Sentra Industri Gerabah Melikan; wawancara dilakukan pada pemerintah, pengelola sentra, maupun beberapa pelaku industri; dan kuesioner dilakukan pada seluruh pelaku industri yang berjumlah populasi 176 pelaku. Penelitian ini menggunakan teknik analisis skoring, yaitu analisis yang menginterpretasi data menjadi suatu skor yang skalatis. Analisis ini digunakan dalam penelitian ini dengan tujuan untuk menganalisis tingkat kesesuaian pada tiap-tiap komponen pariwisata berbasis sentra industri gerabah. Analisis ini secara lebih detail dituangkan pada Tabel 1.

Tabel 1. Operasionalisasi Variabel Penelitian

\begin{tabular}{|c|c|c|c|c|c|}
\hline Variabel & $\begin{array}{c}\text { Definisi } \\
\text { Operasional }\end{array}$ & Parameter & $\begin{array}{l}\text { Kesesuaian } \\
\text { Rendah }\end{array}$ & $\begin{array}{l}\text { Indikator } \\
\text { Kesesuaian } \\
\text { Sedang }\end{array}$ & $\begin{array}{c}\text { Kesesuaian } \\
\text { Tinggi }\end{array}$ \\
\hline $\begin{array}{l}\text { Area } \\
\text { Pembuatan } \\
\text { Gerabah } \\
\text { Wisata }\end{array}$ & $\begin{array}{l}\text { Besaran area } \\
\text { pembuatan } \\
\text { gerabah khusus } \\
\text { wisata di } \\
\text { kawasan }\end{array}$ & $\begin{array}{l}\text { Semakin tersedia luasan } \\
\text { pembuatan gerabah khusus } \\
\text { wisata maka semakin sesuai }\end{array}$ & $\begin{array}{l}\text { Kurang dari } 33,3 \\
\% \text { dari luas } \\
\text { minimal } \\
\text { ketentuan }\end{array}$ & $\begin{array}{l}\text { Sebesar antara } \\
33,3-66,7 \% \text { dari } \\
\text { luas minimal } \\
\text { ketentuan }\end{array}$ & $\begin{array}{l}\text { Lebih dari } 66,7 \% \\
\text { dari luas minimal } \\
\text { ketentuan }\end{array}$ \\
\hline $\begin{array}{l}\text { Luas } \\
\text { Terdampak } \\
\text { Tungku } \\
\text { Pembakaran }\end{array}$ & $\begin{array}{c}\text { Keterdampakkan } \\
\text { kawasan akibat } \\
\text { asap } \\
\text { pembakaran } \\
\text { gerabah } \\
\end{array}$ & $\begin{array}{l}\text { Semakin bebas dari dampak } \\
\text { asap tungku pembakaran } \\
\text { gerabah maka semakin sesuai }\end{array}$ & $\begin{array}{l}\text { Kurang dari } 33,3 \\
\% \text { dari luas } \\
\text { kawasan tidak } \\
\text { terdampak asap }\end{array}$ & $\begin{array}{c}\text { Sebesar antara } \\
33,3-66,7 \% \text { dari } \\
\text { luas kawasan tidak } \\
\text { terdampak asap }\end{array}$ & $\begin{array}{l}\text { Lebih dari } 66,7 \% \\
\text { dari luas kawasan } \\
\text { tidak terdampak } \\
\text { asap }\end{array}$ \\
\hline $\begin{array}{l}\text { Ketersediaan } \\
\text { Jalan } \\
\text { Kawasan }\end{array}$ & $\begin{array}{c}\text { Ketersediaan } \\
\text { lebar menurut } \\
\text { kelas jalan di } \\
\text { dalam kawasan. }\end{array}$ & $\begin{array}{l}\text { Semakin sesuai lebar jalan } \\
\text { kawasan terhadap ketentuan } \\
\text { lebar kelas jalan maka } \\
\text { semakin sesuai }\end{array}$ & $\begin{array}{c}\text { - Jalan Arteri } \\
\text { dengan lebar < } \\
7 \text { meter } \\
\text { - Jalan Kolektor } \\
\text { dengan lebar < } \\
6 \text { meter }\end{array}$ & $\begin{array}{c}\text { - Jalan Arteri } \\
\text { dengan lebar }=7 \\
\text { meter } \\
\text { - Jalan Kolektor } \\
\text { dengan lebar =6 } \\
\text { meter }\end{array}$ & $\begin{array}{c}\text { - Jalan Arteri } \\
\text { dengan lebar }>7 \\
\text { meter } \\
\text { - Jalan Kolektor } \\
\text { dengan lebar }>6 \\
\text { meter }\end{array}$ \\
\hline
\end{tabular}




\begin{tabular}{|c|c|c|c|c|c|}
\hline Variabel & $\begin{array}{c}\text { Definisi } \\
\text { Operasional }\end{array}$ & Parameter & $\begin{array}{l}\text { Kesesuaian } \\
\text { Rendah }\end{array}$ & $\begin{array}{l}\text { Indikator } \\
\text { Kesesuaian } \\
\text { Sedang }\end{array}$ & $\begin{array}{l}\text { Kesesuaian } \\
\text { Tinggi }\end{array}$ \\
\hline & & & $\begin{array}{c}\text { - Jalan lokal } \\
\text { dengan lebar } \\
\text { jalan }<2 \text { meter } \\
\text { - Jalan } \\
\text { lingkungan } \\
\text { lebar }<2 \text { meter }\end{array}$ & $\begin{array}{c}\text { - Jalan lokal } \\
\text { dengan lebar } \\
\text { jalan }=2 \text { meter } \\
\text { - Jalan lingkungan } \\
\text { lebar }=2 \text { meter }\end{array}$ & $\begin{array}{c}\text { - Jalan lokal } \\
\text { dengan lebar } \\
\text { jalan }>2 \text { meter } \\
\text { - Jalan lingkungan } \\
\text { lebar }>2 \text { meter }\end{array}$ \\
\hline $\begin{array}{l}\text { Jangkauan } \\
\text { Parkir Wisata }\end{array}$ & $\begin{array}{l}\text { Keterjangkauan } \\
\text { tempat parkir di } \\
\text { kawasan. }\end{array}$ & $\begin{array}{c}\text { Semakin terjangkaunya } \\
\text { kawasan terhadap lokasi } \\
\text { parkir, yaitu dengan jarak } 400 \\
\text { meter, maka semakin sesuai. }\end{array}$ & $\begin{array}{l}\text { Kurang dari 33,3 } \\
\% \text { dari luas } \\
\text { kawasan } \\
\text { terjangkau parkir }\end{array}$ & $\begin{array}{c}\text { Sebesar antara } \\
33,3-66,7 \% \text { dari } \\
\text { luas kawasan } \\
\text { terjangkau parkir }\end{array}$ & $\begin{array}{l}\text { Lebih dari } 66,7 \% \\
\text { dari luas kawasan } \\
\text { terjangkau parkir }\end{array}$ \\
\hline $\begin{array}{l}\text { Ketersediaan } \\
\text { Tempat } \\
\text { Sampah } \\
\text { Kawasan }\end{array}$ & $\begin{array}{l}\text { Ketersediaan } \\
\text { tempat sampah } \\
\text { di sepanjang } \\
\text { jalan kawasan }\end{array}$ & $\begin{array}{c}\text { Semakin terjangkaunya jarak } \\
\text { antar tempat sampah maka } \\
\text { semakin sesuai, yaitu sejarak } \\
20 \text { meter, maka semakin } \\
\text { sesuai. } \\
\end{array}$ & $\begin{array}{l}\text { Kurang dari } 33,3 \\
\% \text { dari luas } \\
\text { kawasan } \\
\text { terjangkau } \\
\text { tempat sampah. }\end{array}$ & $\begin{array}{c}\text { Sebesar antara } \\
33,3-66,7 \% \text { dari } \\
\text { luas kawasan } \\
\text { terjangkau tempat } \\
\text { sampah } \\
\end{array}$ & $\begin{array}{c}\text { Lebih dari } 66,7 \% \\
\text { dari luas kawasan } \\
\text { terjangkau tempat } \\
\text { sampah }\end{array}$ \\
\hline $\begin{array}{l}\text { Ketersediaan } \\
\text { Listrik } \\
\text { Kawasan }\end{array}$ & $\begin{array}{l}\text { Ketersediaan } \\
\text { listrik di kawasan }\end{array}$ & $\begin{array}{c}\text { Semakin tinggi daya listrik } \\
\text { kawasan maka semakin } \\
\text { sesuai. }\end{array}$ & $\begin{array}{c}\text { Daya listrik } \\
\text { industri }<900 \mathrm{~V}\end{array}$ & $\begin{array}{l}\text { Daya listrik industri } \\
\quad=900 \mathrm{~V}\end{array}$ & $\begin{array}{c}\text { Daya listrik industri } \\
>900 \mathrm{~V}\end{array}$ \\
\hline $\begin{array}{l}\text { Kualitas Air } \\
\text { Bersih } \\
\text { Kawasan }\end{array}$ & $\begin{array}{l}\text { Ketersediaan } \\
\text { sumber air di } \\
\text { kawasan }\end{array}$ & $\begin{array}{l}\text { Semakin jernih sumber air } \\
\text { kawasan maka semakin } \\
\text { sesuai. }\end{array}$ & $\begin{array}{l}\text { Sumber air dari } \\
\text { sungai }\end{array}$ & $\begin{array}{l}\text { Sumber air dari } \\
\text { sumur }\end{array}$ & $\begin{array}{l}\text { Sumber air dari } \\
\text { PDAM }\end{array}$ \\
\hline
\end{tabular}

\section{HASIL DAN PEMBAHASAN}

Sentra Industri Melikan merupakan sentra industri yang berada di perbatasan dua kecamatan di Kabupaten Klaten, yaitu antara Kecamatan Wedi dan Kecamatan Bayat. Sentra industri ini sebagian berada di Desa Melikan, Kecamatan Wedi dan sebagian yang lain berada di Desa Paseban, Kecamatan Bayat. Sentra Industri Gerabah Melikan berada di atas lahan dengan luas sekitar $20 \mathrm{Ha}$. Sentra Industri Melikan memiliki 176 unit industri gerabah skala rumah tangga dengan jumlah tenaga kerja mencapai 300 pekerja. Sentra Industri Gerabah Melikan memiliki 5 paguyuban industri yang menampung para pekerja serta menjadi wadah komunikasi dan bertukar pikiran antar anggota penggiat kreasi gerabah.

\subsection{KETERSEDIAAN AREA PEMBUATAN GERABAH WISATA PADA SENTRA INDUSTRI GERABAH MELIKAN}

Ketersediaan pembentukan gerabah wisata ini bertujuan untuk mengetahui ada tidaknya tempat pembentukan gerabah atau ruang workshop yang dapat digunakan untuk kegiatan pembuatan gerabah bagi wisatawan. Sentra Industri Gerabah Melikan terdapat 35 titik lokasi dengan $683,4 \mathrm{~m}^{2}$ yang menyediakan tempat pembuatan gerabah untuk praktik wisatawan. Pengadaan suatu tempat untuk proses workshop, atau suatu laboratorium, atau suatu tempat yang berguna untuk melakukan praktik haruslah setidaknya mampu menampung 50 orang dengan luas per orang, yaitu $2,5 \mathrm{~m}^{2}$ atau dengan kata lain minimal mempunyai $125 \mathrm{~m}^{2}$ (Republik Indonesia, 2014a). Semakin luas tempat untuk melakukan kegiatan praktik, maka semakin memiliki dukungan yang besar. Pada kawasan sentra ruang untuk melakukan praktik setidaknya telah terpenuhi luasan tersebut. Hal ini menunjukkan bahwa tempat pembuatan gerabah khusus wisatawan pada kawasan sudah mendukung kegiatan wisata.

\subsection{AREA TERDAMPAK TUNGKU PEMBAKARAN PADA SENTRA INDUSTRI GERABAH MELIKAN}

Proses industri dalam memproduksi gerabah yang paling menimbulkan dampak sekitar, yaitu proses pembakaran gerabah. Proses pembakaran gerabah menimbulkan asap yang dapat menjadi gangguan bagi para wisatawan yang berkunjung di Sentra Industri Gerabah Melikan. Asap pembakaran biasanya dapat mencapai satu atau dua rumah atau sekitar 15 meter dari tungku pembakaran. Asap pembakaran gerabah bagi warga sekitar tentu tidak terlalu dipikirkan karena hampir setiap warga merupakan pelaku industri gerabah sehingga membutuhkan adanya pembakaran untuk gerabahnya. Namun bagi wisatawan yang berkunjung, asap sisa pembakaran industri gerabah menjadi gangguan. Jangankan asap pembakaran, bagi banyak 
wisatawan asap rokok pun merupakan suatu gangguan dalam melakukan perjalanan wisata (Fikra \& Khaidir, 2019). Berikut merupakan kesesuaian lokasi pembakaran gerabah yang dapat dilihat pada Gambar 1.

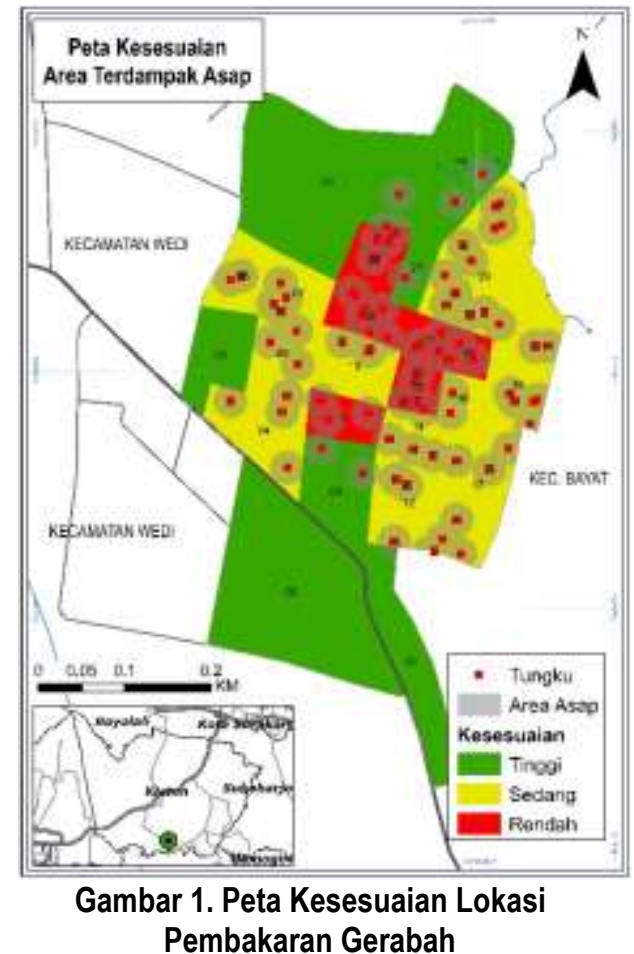

Pada kawasan Sentra Industri Gerabah Melikan, pembakaran dilakukan pada tungku-tungku pembakaran yang berada di dalam kawasan. Pembakaran oleh industri dilakukan tepatnya pada tungku di dekat tempat pembuatan gerabahnya. Tungkutungku ini tidak dimiliki oleh pemerintah maupun komunitas, tetapi merupakan milik perseorangan. Industri yang tidak memiliki tungku biasanya meminjam miliki industri terdekat ataupun bahkan secara kolektif melakukan pembakaran secara bersama dengan industri terdekatnya. Jadi tungku-tungku di kawasan tidak menjadi suatu zona, namun tersebar di penjuru kawasan sentra.

Awal mulanya, tungku hanya dimiliki oleh beberapa orang saja. Setiap industri yang ingin melakukan pembakaran, maka harus memindahkan gerabah setengah jadinya ke lokasi tungku yang jaraknya bisa jadi lumayan jauh. Namun, mulai 2005 tepatnya sejak setelah peristiwa Gempa Jogja diketahui banyak industri yang mengajukan bantuan untuk membangun kediaman yang telah roboh. Mulai saat itu juga banyak tungku pembakaran yang bermunculan, hingga saat ini di dekat industri pasti telah terdapat minimal satu tungku pembakaran. Keadaan ini tentu dari sisi industri merupakan hal baik karena akan meminimalisir beberapa hal, seperti jarak dari industri ke pembarakan tidak lagi menjadi jauh sehingga dapat meminimalisir tenaga, hingga keretakan atau pecahnya gerabah selama perjalanan, serta juga tidak perlunya untuk antri dalam penggunaan tungku sehingga meminimalisir waktu.

Keberadaan tungku pembakaran yang telah tersebar di seluruh penjuru kawasan ini merupakan hal baik bagi industri, namun jika dilihat dari sektor wisata maka ini merupakan hal yang kurang baik. Sektor wisata menekankan pada kenyamanan bagi wisatawan dalam berkunjung, sedangkan keberadaan tungku yang tersebar di penjuru kawasan ini merupakan suatu gangguan bagi kenyamanan wisatawan dalam berkunjung ke kawasan. Hal ini merupakan hal yang tidak mudah untuk diintervensi.

Secara keseluruhan kawasan, hanya sekitar 67 persen lokasi yang tidak terdampak asap. Lokasi yang tidak terdampak tersebut juga berada di lokasi-lokasi yang justru minim bahkan tidak ada atraksi, seperti di bagian pinggir-pinggir kawasan yang minim kegiatan wisata. Sedangkan, di bagian pusat sentra justru memiliki dampak tungku pembakaran yang cukup 
signifikan. Oleh karenanya, lokasi-lokasi tungku pembakaran yang dapat mempengaruhi kenyamanan wisatawan ini berkemungkinan besar menjadi hambatan tersendiri bagi keberlangsungan kegiatan wisata kawasan.

\subsection{KETERSEDIAAN JALAN PADA SENTRA INDUSTRI GERABAH MELIKAN}

Ketersediaan jalan kawasan dapat diketahui dengan penilaian berdasarkan lebar jalan dari persentase panjang jalan dan kelas jalan. Pada jalan kawasan hanya terdapat 2 (dua) kelas jalan, yaitu kolektor dan lingkungan. Jaringan jalan melayani keberadaan wisata di kawasan. Jalan sangat penting bagi para wisatawan yang ingin menikmati objek-objek wisata di dalam kawasan (Joehastanti, 2012). Jalan yang tidak sesuai akan berdampak pada tidak optimalnya kunjungan wisata kawasan, atau lebih tepatnya wisatawan merasa tidak nyaman menggunakan jalan kawasan tersebut.

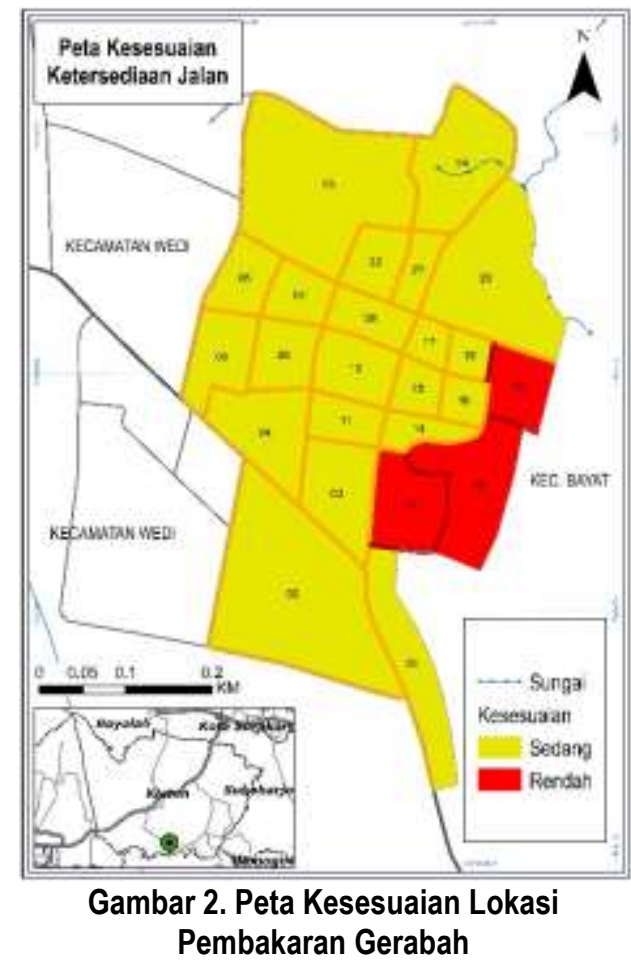

Pada kawasan sentra industri gerabah tidak terdapat jalan dengan kesesuaian tinggi, dan hampir semua jalannya memiliki kesesuaian sedang (lihat Gambar 2). Jalan masuk ke kawasan sentra maupun jalan di dalam sentra terutama yang berada di utara Jalan Raya Bayat-Wedi memiliki lebar yang tergolong sempit. Hampir di seluruh jalan kawasan hanya mampu menampung satu mobil ukuran sedang satu arah, tidak mampu untuk menampung mobil dua arah. Terlebih lagi di bagian timur kawasan, bahkan tidak bisa dilalui mobil karena jalannya sangat sempit dengan tanah yang naik turun dan tidak rata. Sedangkan untuk jalan di selatan Jalan Raya, mampu dilalui oleh bus besar.

Kawasan sentra industri gerabah, terutama di bagian utara jalan raya merupakan kawasan yang padat bangunan permukiman. Jalan di bagian tersebut sebagian besar tidak memiliki bahu jalan, sehingga tidak memungkinkan untuk diperlebar. Sehingga keadaan jalan di kawasan ini merupakan keadaan yang susah bahkan mungkin tidak bisa diintervensi. Oleh karena itu, kesesuaian jalan di kawasan hanya masuk kategori kesesuaian sedang dalam mendukung kawasan wisata.

\subsection{JANGKAUAN PARKIR WISATA PADA SENTRA INDUSTRI GERABAH MELIKAN}

Pada suatu kawasan wisata, lokasi tempat parkir merupakan faktor yang sangat penting. Lokasi parkir yang terlalu jauh akan membuat wisatawan berpikir ulang untuk melakukan kunjungan wisata. Hal tersebut tentu akan menyulitkan wisatawan ketika berkunjung ke kawasan. Sedangkan, lokasi parkir yang mudah menjangkau lokasi destinasi tentu akan memudahkan wisatawan dalam berkunjung. Jarak lokasi parkir menuju destinasi idealnya , yaitu maksimal 400 meter, semakin dekat maka semakin sesuai. 


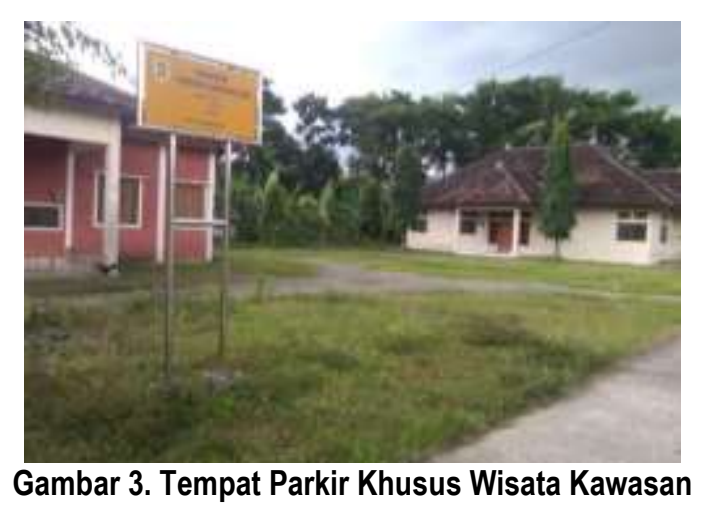

Pada kawasan pariwisata, lokasi tempat parkir khusus wisatawan yang berkunjung hanya memiliki satu lokasi, yaitu di 150 meter bagian selatan Jalan Raya Bayat-Wedi (Gambar 3). Lokasi tempat parkir ini memang memiliki luas $550 \mathrm{~m}^{2}$ sehingga mampu menampung beberapa bus besar. Namun yang menjadi kendala adalah lokasi parkirnya yang justru berada di bagian selatan kawasan terlebih lagi di selatan jalan raya. Padahal, lokasi atraksi industri gerabah justru berada di bagian utara jalan raya. Meskipun masih dalam satu kawasan, namun keberadaan lokasi yang lumayan jauh dari kumpulan atraksi ini menyebabkan wisatawan harus berjalan. Pada jarak ratusan meter lokasi wisatawan berjalan dari lokasi parkir ke lokasi atraksi, sama sekali belum terdapat fasilitas-fasilitas yang dapat mempermudah mobilitas, misalnya sepeda, kereta angkut kecil, ataupun lainnya. Oleh karena itu, wisatawan murni harus berjalan kaki dari lokasi parkir tersebut.

Pada bagian utara kawasan sebenarnya telah terdapat lahan yang sedang direncanakan untuk parkir. Lokasi ini dipilih karena bagian utara inilah tanah yang dimiliki desa serta saat ini masih berupa lahan kosong. Rencana ini memiliki beberapa kendala, yaitu lokasi ini hanya bisa dicapai maksimal dengan mobil ukuran sedang sementara kendaraan bus tidak akan mampu mencapai lokasi ini. Setiap jalan yang menuju lokasi ini memiliki lebar jalan yang sempit, rata-rata hanya sekitar 2 meter. Lebar jalan tersebut hanya mampu dilalui sebuah mobil dan tidak bisa untuk dua arah. Keberadaan rencana parkir di utara ini juga masih belum bisa menyelesaikan masalah bagi para wisatawan yang datang dengan rombongan yang menggunakan bus wisata karena masih akan tetap berada di lokasi parkir selatan jalan raya.

\subsection{KETERSEDIAAN TEMPAT SAMPAH KAWASAN PADA SENTRA INDUSTRI GERABAH MELIKAN}

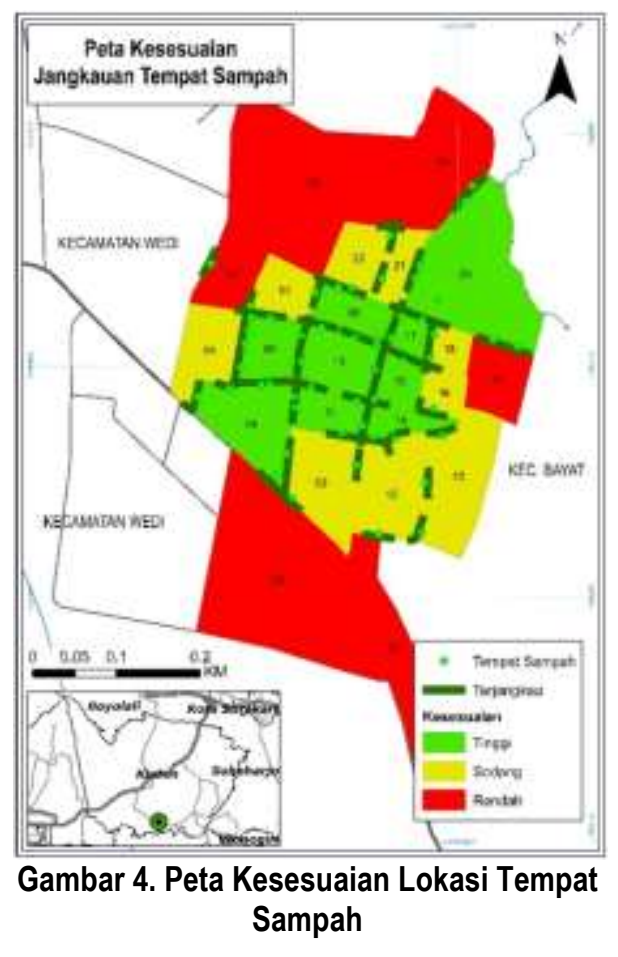


Wisatawan yang berkunjung di kawasan, tentunya akan ditawarkan pada salah satu atraksi, yaitu jalan-jalan di kawasan untuk melihat pameran gerabah di sepanjang jalan. Kegiatan wisatawan yang berlangsung di sepanjang jalan dalam kawasan ini tentunya membutuhkan salah satunya tempat sampah. Jangan sampai wisatawan menjadi disusahkan karena tidak terpenuhinya kebutuhan tempat sampah di sepanjang jalan wisata, atau juga jangan sampai wisatawan membuang sampah miliknya sembarangan. Menurut Danoe dalam Handayani (2018), kegiatan jalan-jalan wisata ini perlu adanya fasilitas berupa tempat-tempat sampah di sepanjang jalan minimal berjarak 20 meter, sehingga wisatawan tidak akan kerepotan ketika hendak membuang sampah.

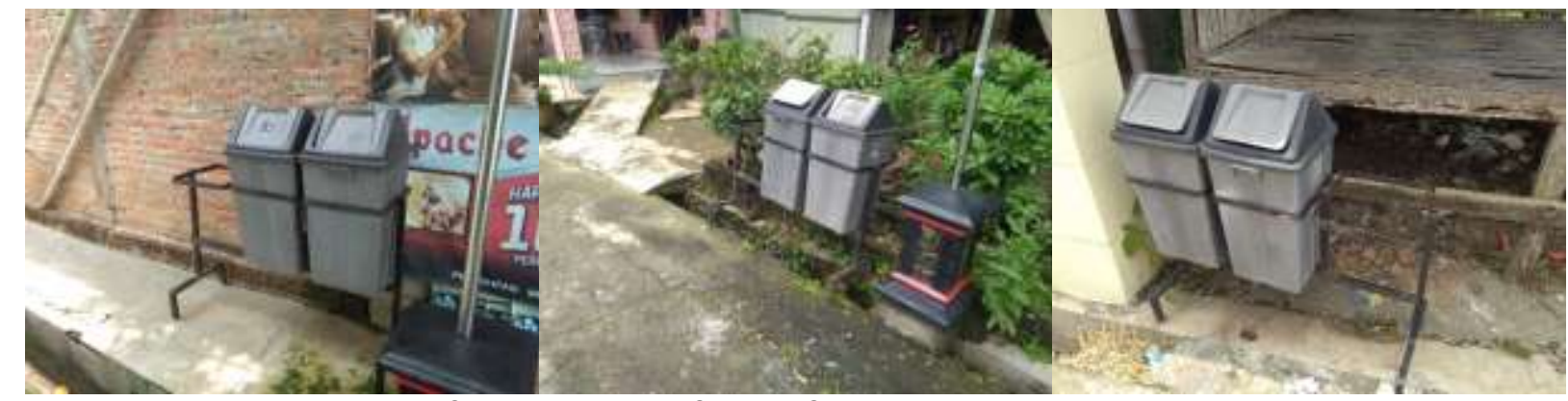

Gambar 5. Tempat Sampah Sepanjang Jalan Kawasan

Pada kawasan sentra industri jika dilihat secara keseluruhan masih banyak penjuru yang belum memiliki tempat sampah di sepanjang jalannya (Gambar 4). Beberapa rensponden mengatakan bahwa pemberian fasilitas untuk memajukan kawasan wisata sepertinya memiliki ketimpangan. Bagian kawasan yang sering diperhatikan merupakan bagian kawasan yang terletak di Desa Melikan itupun bagian yang dekat dengan Jalan Raya Bayat-Wedi. Padahal di setiap penjuru kawasan telah diminta partisipasinya untuk memajukan kawasan sebagai destinasi wisata gerabah. Hal ini juga mempengaruhi keberadaan tempat sampah di sepanjang jalan kawasan sentra. Keberadaan tempat sampah paling memenuhi kriteria hanya berada di bagian tengah kawasan sentra, khususnya tepat di bagian utara jalan raya (Gambar 5). Mengingat tempat sampah bukanlah suatu komponen yang sulit untuk diadakan maka ke depannya tentu dapat diintervensi oleh stakeholder terkait. Meskipun demikian, untuk saat ini tempat sampah memang masih sangat kurang dan masih terjadi ketidakmerataan di kawasan.

\subsection{KETERSEDIAAN LISTRIK PADA SENTRA INDUSTRI GERABAH MELIKAN}

Ketersediaan jaringan listrik di kawasan dalam melayani kegiatan wisatawan juga harus diperhatikan mengingat di jaman modern wisatawan tidak lepas dari barang-barang elektronik, seperti ponsel. Foto merupakan hal wajib ketika sedang berwisata karena foto menjadi arsip pribadi atau juga untuk pamer kepada orang lain (Antopani, 2015).

Ketersediaan listrik pada industri gerabah di kawasan sentra industri secara keseluruhan tidak memiliki kendala. Keseluruhan industri telah memiliki aliran listrik, dari yang berdaya 450V hingga di atas 900V. Hal ini tentu membuat kawasan tidak perlu khawatir dalam ketersediaan listrik, mengingat juga pembuatan gerabah tidak membutuhkan listrik secara langsung, meskipun wisatawan kadang-kadang memerlukan listrik untuk mengisi ponsel jika tiba-tiba mati.

Aliran listrik di kawasan murni dari daya PLN, kawasan tidak mempunyai pembangkit listrik mandiri. Pembangkit listrik diperlukan jika listrik PLN tiba-tiba mati, mengingat wisatawan dalam berwisata terutama ketika melakukan pembuatan gerabah secara tidak langsung akan berkemungkinan memerlukan listrik, seperti untuk mengisi daya ponsel maupun untuk penerangan.

\subsection{KESESUAIAN KUALITAS AIR BERSIH PADA SENTRA INDUSTRI GERABAH MELIKAN}

Proses pembuatan gerabah salah satunya menggunakan bahan berupa air. Sedangkan wisatawan yang berkunjung di kawasan atraksi yang utama tentunya adalah proses pembuatan gerabah. Para wisatawan dapat mencoba bagaimana membentuk gerabah dengan tangannya sendiri. Air yang digunakan untuk bahan tambahan dalam proses pembuatan tersebut haruslah air yang kualitasnya terjamin, sehingga tidak mempengaruhi kesehatan wisatawan. Air yang kotor akan membuat wisatawan enggan untuk melakukan proses wisata pembuatan gerabah ini (Wiradiputra \& Brahmanto, 2016). 
Untuk ketersediaan air bersih, dalam kawasan sentra telah memiliki kesesuaian sedang, di mana seluruh industri gerabah di kawasan menggunakan air sumur sebagai air untuk pembuatan gerabah. Di kawasan sentra sendiri belum teraliri air dari perusahaan air bersih, sehingga masih menggunakan air sumur. Kebutuhan air di kawasan tidak mungkin menggunakan sungai karena di kawasan sentra sendiri minim air sungai, sungai hanya nampak di bagian utara kawasan itupun dengan air yang sangat sedikit di musim selain penghujan. Ini menunjukkan bahwa kualitas air yang digunakan untuk melakukan pembuatan gerabah tergolong air dengan kualitas sedang.

\subsection{KESESUAIAN FASILITAS UNTUK MENDUKUNG PENGEMBANGAN PARIWISATA PADA SENTRA INDUSTRI GERABAH MELIKAN}

Fasilitas pelayanan wisata merupakan hal kedua setelah atraksi wisata, yang setidaknya harus ada di suatu kawasan wisata. Fasilitas tersebut ditinjau dari 7 sub komponen yang masing-masing menunjukkan tingkat kesesuaian dukungan yang berbeda. Terdapat dua kelompok tingkat kesesuaian dukungan yang dapat dilihat pada Tabel 2, yaitu kesesuaian tinggi dan kesesuaian sedang. Kesesuaian tinggi dimiliki oleh dua sub komponen, yaitu ketersediaan area pembuatan gerabah wisata dan area terdampak tungku pembakaran. Kesesuaian tinggi pada dua sub komponen ini berarti dua sub komponen ini sudah memiliki dukungan yang tinggi terhadap pengembangan kawasan wisata. Sedangkan, sebanyak 5 sub komponen masih memiliki kesesuaian sedang, atau dengan kata lain belum mampu mendukung pengembangan kegiatan wisata di kawasan.

Tabel 1. Hasil Penelitian

\begin{tabular}{clcc}
\hline No & \multicolumn{1}{c}{ Komponen } & Skor/Persen & $\begin{array}{c}\text { Tingkat } \\
\text { Kesesuaian }\end{array}$ \\
\hline 1 & Ketersediaan Area Pembuatan Gerabah Wisata & $100 \%$ & Tinggi \\
2 & Area Terdampak Tungku Pembakaran & $67.7 \%$ & Tinggi \\
3 & Ketersediaan Jalan Kawasan & $1.93($ dari 1-3) & Sedang \\
4 & Jangkauan Parkir Wisata & $36.2 \%$ & Sedang \\
5 & Ketersediaan Tempat Sampah Kawasan & $47.2 \%$ & Sedang \\
6 & Ketersediaan Listrik Kawasan & $2.1($ dari 1-3) & Sedang \\
7 & Kualitas Air Bersih Kawasan & $100 \%$ & Sedang \\
Total & $2.2($ dari 1-3) & Sedang \\
\hline
\end{tabular}

Secara keseluruhan, tingkat kesesuaian fasilitas pada Sentra Industri Gerabah Melikan untuk kegiatan pariwisata hanya memiliki kesesuaian sedang dengan nilai 2,2 dari 1-3 poin. Hal ini menunjukkan bahwa keberadaan fasilitas kawasan sentra gerabah ini masih belum atau kurang mampu dalam mendukung pengembangan kegiatan kawasan wisata.

\section{KESIMPULAN}

Kesesuian fasilitas Sentra Industri Gerabah Melikan untuk mendukung kegiatan wisata di kawasan hanya mencapai nilai 2,2 dari rentan 1-3, atau dengan kata lain memiliki kesesuaian sedang. Hal tersebut berarti fasilitas sentra berada di antara 'sesuai' dan 'tidak sesuai'. Fasilitas sentra tidak bisa jika dikatakan 'tidak sesuai', namun juga belum bisa jika dikatakan 'sesuai'. Fasilitas berupa ketersediaan area pembuatan gerabah khusus wisatawan dan area terdampak tungku pembakaran telah memiliki nilai kesesuaian tinggi, namun untuk fasilitas lainnya masih dalam golongan nilai kesesuaian sedang. Oleh karena itu, fasilitas secara keseluruhan yang menjadi objek penelitian ini masih kurang mampu dalam mendukung Sentra Industri Gerabah Melikan sebagai kawasan pariwisata.

\section{UCAPAN TERIMA KASIH}

Penulis mengucapkan terima kasih kepada pihak yang telah memberikan dukungan dalam penyusunan penelitian ini, khususnya pihak-pihak dari Sentra Industri Gerabah Melikan, Pemerintah Kabupaten Klaten, dan Program Studi Perencanaan Wilayah dan Kota Fakultas Teknik Universitas Sebelas Maret. 


\section{DAFTAR PUSTAKA}

Adisasmita, R. (2010). Pembangunan Kawasan dan Tata Ruang. Yogyakarta: Graha llmu.

Antaqona, G. (2012). Desa Wisata: Gerabah Miring dari Melikan. Retrieved August 11, 2021, from solopos.com website: https://www.solopos.com/desa-wisata-gerabah-miring-dari-melikan-163685

Antariksa, B. (2010). Konsep Indonesia Kreatif: Tinjauan Awal Mengenai Peluang dan Tantangan bagi Pembangunan Indonesia. Pusat Penelitian Dan Pengembangan Kebijakan Kepariwisataan Kementerian Pariwisata Dan Ekonomi Kreatif. Retrieved from https://www.kemenparekraf.go.id/asset_admin/assets/uploads/media/old_file/Zona Kreatif.pdf

Antopani, T. (2015). Fotografi, Pariwisata, dan Media Aktualisasi Diri. Jurnal Rekam, 11(1), 31-40. https://doi.org/10.24821/rekam.v11i1.1293

Cidhy, D. A. T. K., Baga, L. M., \& Djohar, S. (2016). Pariwisata Kreatif Dan Kegiatan Ekstrakurikuler Berbasis Bambu Dalam Pengembangan Model Bisnis Cv Suratin Bamboo. Jurnal Manajemen Dan Agribisnis, 13(3), 227-239. https://doi.org/10.17358/jma.13.3.227

Fikra, N., \& Khaidir, A. (2019). PEMANFAATAN BIS CITY TOUR SEBAGAI PROMOSI WISATA. Ranah Research: Journal of Multidicsiplinary Research and Development, 1(3), 407-415. Retrieved from https://jurnal.ipb.ac.id/index.php/jmagr/article/view/14177 doi: 10.17358/jma.13.3.227

Hanafi, M. (2010). Perancangan Ulang Fasilitas Kerja Alat Pembuat Gerabah Dengan Mempertimbangkan Aspek Ergonomi. Universitas Sebelas Maret.

Handayani, S., Irwansyah, M., \& Isya, M. (2018). Tinjauan Sarana Dan Prasarana Jalur Pedestrian Di Kawasan Peunayong, Banda Aceh. Jurnal Arsip Rekayasa Sipil Dan Perencanaan, 1(1), 72-80. https://doi.org/10.24815/jarsp.v1i1.10357

Joehastanti, J. (2012). Strategi Pemasaran Wisata Alam Untuk Meningkatkan Kunjungan Wisatawan Di Kawasan Wisata Kabupaten Kediri. Jurnal IImu Manajemen: Revitalisasi, 1(2), 61-73.

Lestari, E. P. (2010). Penguatan Ekonomi Industri Kecil dan Menengah Melalui Platform Klaster Industri. Jurnal Organisasi Dan Manajemen, 6(2), 146-157. Retrieved from http://jurnal.ut.ac.id/index.php/JOM/article/view/289

Nurmansyah, A. (2014). Potensi Pariwisata dalam Perekonomian Indonesia. Jurnal Ekonomi Bisnis \& Kewirausahaan, 3(1), 45-61. Retrieved from http://jurnal.usahidsolo.ac.id/index.php/IAB/article/view/52

Purnomo, A. (2016). Strategi Pengembangan Produk Unggulan Kawasan Sentra Industri Kecil Keripik di Kota Bandar Lampung. Sosialita: Jurnal IImu Administrasi, 8(1), 50-56. Retrieved from https://www.neliti.com/id/publications/163566/strategi-pengembangan-produkunggulan-kawasan-sentra-industri-kecil-keripik-di-k\#cite

Republik Indonesia. (2009). Undang-Undang Nomor 10 Tahun 2009 tentang Kepariwisataan. Retrieved from https://www.kemenparekraf.go.id/asset_admin/assets/uploads/media/old_file/4636_1364-UUTentangKepariwisataannet1.pdf

Republik Indonesia. (2014a). Peraturan Menteri Pendidikan Dan Kebudayaan Republik Indonesia Nomor 49 Tahun 2014 Tentang Standar Nasional Pendidikan Tinggi. Retrieved from https://www.unpad.ac.id/wpcontent/uploads/2014/06/permen_tahun2014_nomor049.pdf

Republik Indonesia. (2014b). Undang-Undang No 3 tahun 2014 Tentang Perindustrian. Retrieved from https://kemenperin.go.id/download/5181/Undang-Undang-No-3-Tahun-2014-Perindustrian

Republik Indonesia. (2014c). Undang-Undang Nomor 6 Tahun 2014 tentang Desa.

Rusnanda, R., Supriadi, E., \& Reza, M. (2016). Kajian Potensi Dan Rekomendasi Desa Lhokrukam Berbasis Desa Wisata, Sebagai Alternatif Pembangunan Kota Tapaktuan. Jurnal Inotera, 1(1), 10-16. https://doi.org/10.31572/inotera.vol1.iss1.2016.id3

Satryanto, R., \& Pamungkas, A. (2015). Analisa Faktor-faktor yang Mempengaruhi Pengembangan Kawasan Wisata Bahari Lhok Geulumpang, Aceh Jaya. JURNAL TEKNIK ITS, 4(1), C6-C10. Retrieved from https://www.onesearch.id/Record/IOS2038.article8962/Details

Sulistiani, \& Munawar, A. (2018). Analisis Fasilitas Parkir Dan Aksesibilitas Obyek Wisata Goa Gong, Pacitan. Jurnal Riset Rekayasa Sipil, 1(2), 71-81. https://doi.org/10.20961/jrs.v1i2.18122

Wiradiputra, F. A., \& Brahmanto, E. (2016). Analisis Persepsi Wisatawan Mengenai Penurunan Kualitas Daya Tarik Wisata Terhadap Minat Berkunjung. Pariwisata, 3(2), 129-137. Retrieved from https://jurnal.uns.ac.id/jrs/article/view/18122

Yoeti, O. A. (1996). Pengantar Ilmu Pariwisata. Bandung: Angkasa. 